\title{
Political Participation of Local Publics in the Unemployment Field: A Comparison of Lyon and Turin
}

\author{
Matteo Bassoli* \& Manlio Cinalli** \\ * School of law, eCampus Online University, Novedrate (CO), Italy. \\ **CEVIPOF, SciencesPo, Paris, France
}

\begin{abstract}
This article focuses on political participation of local publics in the unemployment field, examining networks of collective actors in Lyon and Turin. Our main question is: Is the participation of local publics fostered under conditions of more developed governance that increases bottom-up access (formal or informal) to elites and institutions in the policy domain? Drawing upon the most recent developments in literatures on social movement theory, governance, and network analysis, this article discusses the main variations in terms of political participation of local publics in Lyon and Turin. It then enquires into the main explanatory factors accounting for these variations, thus showing that the openness of governance does influence the level of political participation of local publics. The main argument is that in an open context participation is low, while in a closed (or underdeveloped) context local publics participate more, with differential access to decision-making according to their resources.
\end{abstract}

Keywords: Local governance, Social networks, Local publics, Unemployment, Multi-organisational field

\section{Introduction}

Unemployment has emerged in the last decades as one of most compelling issues in Europe. Eurostat data show increasing unemployment rates, particularly for the younger cohorts of populations (Eurostat 2011). The European Commission has provided funds to implement relevant measures through Structural Funds, promoting policy interventions that are flexible enough to allow for distinct national answers and participation of the largest possible number of private and public stakeholders. For example, in the aftermath of economic recession of late 2000s, both the European Commission and the Council of Europe have focused on the inclusion of the unemployed through interventions such as the 'Agenda 2020', providing a comprehensive policy effort that is cross-sectorial and highly articulated. Within Europe, however, unemployment has been more significant in some places than in others. In what follows, we compare two cities, Lyon and Turin, which are located in two European countries with traditionally high rates of unemployment. Whether referring to 'precarious' workers, the 'excluded', or to more colourful expressions such as the Italian 'cococo', unemployment and precariousness have stood out in France and Italy as the objects of political intervention throughout the 2000s. In addition, both countries share a number of common political dynamics, such as the predominance of right-wing politics at a general level, ${ }^{1}$ a slow yet consistent attempt

${ }^{1}$ In Italy the right gained control of the government in 2001. The ephemeral return of the left to power between 2006 and 2008 had no major consequence, particularly in terms of unemployment policy. In 
to increase the flexibility of labour market access, and a focus on redistribution of job opportunities in public rhetoric.

This article uses a network approach to deal with the interplay of organisational attributes, on the one hand, and multi-level opportunity structures on the other hand. The main aim is to account for variations of political participation across a large range of organisations that engage in the unemployment field. In particular, our argument promotes the use of the relational approach already used in social movement scholarship (Diani 1992 and 1995; Gould 1995; Diani and McAdam 2003; Diani and Bison 2004), but with a different emphasis derived from literature on governance (Cinalli 2007a; Christopoulos 2008; Christopoulos and Quaglia 2009; Feiock and Scholz 2010; Sohn and Giffinger 2015). Instead of using networks to understand the nature of social movements, the governance literature has used relational data to examine the different levels of actors' involvement in the political sphere. Scholars have also focused on informal groups, associations, cooperatives and unions (Piselli and Ramella 2008), providing the possibility of testing different theories of political participation (resource-based or social capital related). Our approach thus offers the possibility to engage in full with the analysis of a whole 'multi-organisational field' (Curtis and Zurcher 1973), allowing for a systematic assessment of political participation within formal and informal decision-making processes.

Hence, 'local publics', which are understood as made up of all organisations that are active in the local public domain, can be placed at the core of a number of questions. What is the relationship between different political contexts and variations in participation of local publics in the unemployment field? What is the space for direct intervention of local publics in governance processes related to unemployment across the two cities of Lyon and Turin? And beyond the role of political opportunities, what is the role of endogenous attributes in predicting the political participation of various actors? Are variations in participation dependent upon activities, for example, the 'policy' or the 'services' orientation that different actors may privilege respectively? And what about the specific role of social capital?

The following section clarifies our theoretical framework in terms of main dependent and independent variables. Afterwards, the article moves on to present relevant contextual information enabling the comparison between Lyon and Turin (section 3). We then proceed in section 4 to identify and measure political participation as a dependent variable. Section 5 examines the relationship between participation and a range of independent variables at the level of collective actors (resources and orientations) and networks in the unemployment field (governance opportunities and relational structures). Finally, section 6 sums up the empirical findings and indicates directions for future research.

\section{Political Context, Governance and Endogenous Characteristics}

Unemployment has stood out as a crucial issue in Europe, leading to demands for 'reforms' of the labour market, social policy, and unemployment regulations. A brief

France the 2000s opened with the "cohabitation" between a right-wing President and a left-wing Prime Minister. But 2002 marked the definitive defeat of the left, as it lost both control of government and its majority in Parliament. 
consideration of these reforms in France and Italy confirms a common trend, with the promotion of a secondary labour market (Jessoula et al. 2010) consisting of mini-jobs and short-term contracts, and the elaboration of restrictive measures to pressure the long-term unemployed into accepting available jobs. The organisations that are active in the unemployment field have thus faced a number of common pressures. Yet it should be emphasised that labour market mechanisms, social protection systems, and social services have remained specific to each distinct nation-state (Cinalli and Giugni 2010). That is, attention needs to be focused on the key role of the political environment in which participation of local publics in Lyon and Turin takes place, following those scholars who argue that the consideration of joblessness as a simple grievance is insufficient to explain political developments and the debate in the unemployment field (Baglioni et al. 2008; Baxandall 2001 and 2002).

Our comparison looks at the role of 'political opportunities' (Tilly 1978, Kitschelt 1986, Kriesi et al. 1995 Tarrow 1998) and 'welfare regimes' (Giugni et al. 2009, Cinalli and Giugni 2010) to account for variations of political participation in the unemployment multi-organisational field. In particular, the specific focus on local publics in Lyon and Turin draws upon a number of studies that, since the seminal work of Eisinger (1973), have emphasised the explanatory role of the sub-national contextual environment, while taking into consideration the complex dynamics linking the public to the policy domain on the one hand (Broadbent 1998) and local to national opportunities on the other (Cinalli and El Hariri 2011; Della Porta and Andretta 2002). Our consideration of the more unstable aspects of the political context (Gamson and Meyer 1996) also aims to link the analysis of 'opportunities' to that of 'governance'. For the latter, we can thus move from a simplistic approach based on distinct sectors (public, private for profit and non-profit) to a more nuanced version based on the concept of (local) governance (Bassoli and Polizzi 2011, Grote 2008, John 2001, Mayntz 2003). We thus follow studies that have dealt with the important role of the local level in policymaking (Harlow and Rawlings 2006, Jordan 2001), focusing on private-public partnership (Osborne 2007), multi-sectorial partnership (Sullivan and Skelcher 2002), and participatory governance arrangements (Bassoli 2010 and 2012; Grote and Gbikpi 2002), such as participatory budgeting. Amongst our dimensions of analysis, we consider how much genuine access private actors have to local policy making, above all in the crucial phase of decision making, but also during discussion and implementation phases (Polizzi 2011).

The existence of political opportunities rooted in local governance cannot be considered the only determinant of participation. Following the long-standing tradition of Resource Mobilization Theory (Obershall 1973, McCarthy and Zald 1977), many studies have shown the importance of budgets, organisational assets, and increasing resource dependence on broader civil society (Giugni and Passy 2001). Accordingly, this article deals with a number of endogenous characteristics that may have an impact on variations in participation of local publics in Lyon and Turin. In particular, we focus on organisational structuring of local publics, how long different organisations have been active in the unemployment field, their degree of formalisation, their ownership of relevant assets such as an office space, as well as the main orientations of actors, identified in their prevailing, engagement in policies or, alternatively, services (Lelieveldt et al. 2007, Torpe and Ferrer-Fons 2007).

In what follows network analysis is used to provide key conceptual and 
methodological tools for examining the multi-level and multi-organisational field of unemployment. ${ }^{2}$ Drawing on previous research that has put the study of relational structures at the core of unemployment politics (Cinalli 2010; Cinalli and Fuglister 2008), our networks are primarily made of collective actors (nodes) connected by three main directed relationships (ties): exchange of information, cooperation in projects, and overlapping members. The field is thus defined in terms of a set of (potentially) reciprocal interactions that represent the possibility of accessing specific resources and additionally behavioural constraints or loyalties that constrain organisations (Cinalli 2007b). For the purpose of the following analysis we also consider administrative level as a node within a 'two-mode network'. Each collective actor may be active at (i.e. connected to) the district, local, national, regional or EU level. We generated several two-mode networks depending on the nature of the relationships represented by network ties and report network densities below. The construction of matrices of connections among collective actors, and between actors and administrative levels also allows graphical representation as in Figures 4.1, 4.2 and 5.1. To deepen our analysis further we also consider the different attributes that our collective actors have (e.g. size or budget), which allows the investigation of correlations between attributes (i.e. variables) and network outcomes through a procedure detailed in section 5 below, On the one hand, therefore, the analysis below assesses the extent to which political participation of local publics in the two cities translates into specific network patterns between local publics and policy actors. These networks are also linked with the concept of social capital (Lin 2001), which is most often understood to increase the organisation's chance of being politically active, given the its number of connections possessed. On the other hand, we examine the roles of a number of additional variables that may account for variations of participation.

Overall, relevant questions for the comparison of local publics in Lyon and Turin are given a relational twist. What are the channels being forged in the two cities across the public and the policy domain at the local level and at the other levels beyond that? Does unemployment stand out as an issue that divides certain types of actors from others? Or, alternatively, do actors of different types forge extensive ties, reducing the traditional distance between them? Different governance dynamics can be disentangled in the multi-level and multi-organisational unemployment field, shedding light on the variety of actors in the public domain and their variable access to the policy domain across different levels (Feiock and Scholz 2010). In doing this, the article further advances the network conceptualisation of governance (Cinalli 2007a; Rhodes 1996 and 1997), responding to the pressing need to use networks as an effective instrument of empirical analysis, rather than as a simple heuristic device (Christopoluos 2008). ${ }^{3}$

\section{Comparing the Unemployment Field in Lyon and Turin}

Having experienced a similar situation of unemployment grievance over the past few years, with peaks in their regions at 9\% (INSEE 2011; ISTAT 2011), Lyon and Turin are comparable on the basis of additional key indicators such as economic size, economic structure, and type of unemployment (level of de-industrialisation). At the

\footnotetext{
${ }^{2}$ For a treatment of network analysis see Knoke and Kuklinsky 1982, Scott 2000, and Wasserman and Faust 1994.

${ }^{3}$ For an overview of broader debate about network analysis and governance see Christopoulos 2008, Dowding 1995, 2001, Marsh and Smith 2001, Marshall and Staehel 2015, and Raab 2001.
}

Deleted: 2 
same time, Lyon and Turin are two major non-capital cities in countries that have gone through a genuine policy of decentralization. In France this process has been sanctioned by the Constitutional Law of March 28, 2003, acknowledging explicitly the role of sub-national authorities. As regards Italy, the Constitutional Law 3/2001 has provided further policy responsibilities to local authorities. The cities also share a number of common political characteristics. Electoral systems in both cities are predominantly majoritarian. In line with the tradition of French Presidentialism, Lyon is characterised by the dominant role of the mayor, but Turin has equally seen the gradual strengthening of the local executive following the law 81/1993 (Fabbrini, 2001). The leftist governments in Lyon and Turin are in opposition to the rightist French and Italian national governments respectively. And both cities lack effective direct democracy tools. ${ }^{4}$

However, the two cities have been facing contrasting policy developments, allowing for the analysis of different answers that policy makers have elaborated at the national and sub-national levels. The welfare literature shows crucial divergences between the French and the Italian model, in spite of their common roots in 'corporatism' (EspingAndersen 1990). In Italy, a key role has been handed over to the family as a crucial agent of social protection (Ferrera 1996), while France has preferred to intervene extensively over welfare in an attempt to reach a virtuous balance between corporatist and universalist prescriptions. Although both countries have engaged in a number of reforms that have targeted the labour market to relax employment protections (OECD 2010), specific policies dealing with unemployment and social inclusion have been developed more extensively in France than in Italy. In particular, the two countries diverge when looking at various indicators of state intervention in terms of unemployment regulations - for example, the pre-requisites for obtaining social provisions, the level and extension of benefit coverage, the role of employment agencies, and the scope of sanctions (Giugni et al. 2009; Cinalli and Giugni 2010). In this context, Italy exhibits a less inclusive unemployment legislation, in which a high share of the workforce has low social protection (Jessoula et al. 2010).

The French unemployment protection system can rely not only on the corporatist legacies such as the régime d'assurance (financed and managed by the trades unions and entrepreneurial associations), but also on the universalist régime de solidarité (financed and managed by the state). By contrast, unemployment provisions and social protection are very limited in Italy, especially for the recent wave of precarious youth, who could join the labour force only as 'atypical' workers. What is more, evidence at the local level shows that the municipality of Turin is less active in unemployment policies than its counterpart in Lyon, which in fact supports an increasing number of projects for job creation. The 'right to experiment', whereby local authorities can diverge from national arrangements, provides the Lyon municipality with further space of intervention in terms of social and economic policy. Differences are also noticeable in terms of public information and support services. Employment offices have been set up in Turin (the Centri per l'impiego), but public information and services are still limited. By contrast, the Maison de l'Emploi et de la Formation in Lyon provides information for the unemployed, helps

\footnotetext{
${ }^{4}$ Local statute in Turin allows only consultative referenda, though they can be proposed by citizens. In Lyon 'decisional referenda' have been instituted in 2003 , yet, they need to be initiated by local authorities.
} 
employers with recruitment, and gathers a large volume of economic and social data.

The local level is also important by virtue of the large volume of actors that it involves in service delivery or policy implementation. Hence, the comparison of Lyon and Turin allows for dealing with key explanatory variables at the local level relating to various organisational resources and the networks created by actors. No doubt, the two cities differ in terms of inclusion of local publics within the policy domain. Lyon has inclusive governance dynamics that are supposed to promote a wider access of local publics to the policy domain. For example, the action of the Maison de l'Emploi et de la Formation has been shaped on the objectives of the 2005 loi de programmation pour la cohésion sociale with the main aim of ensuring a stronger partnership of actors in the public sector alongside representatives of civil society. By contrast, Turin stands out for its restrictive stance in terms of governance arrangements owing to the marginal participation of public domain actors in the policy process. While relevant competences are often located beyond the scope of the municipality, ${ }^{5}$ the vast externalisation to private actors at the local level has brought about a clear shift of responsibility from public to private actors in the delivery of social services (Ranci 1999; Ranci and Montagnini 2009). Two actors play a pivotal role in the Italian labour market: the agenzie interinali (recruitment agencies) and the sistema cooperativo (cooperative system). The latter has been regulated by the national law so as to promote employability of young people and of the long-term unemployed. As regards the agenzie interinali, they are private enterprises that take care of 'temping', dealing with different administrative procedures related to fixedterm contracts or jobs on demand.

\section{Local Publics in Lyon and Turin}

Our research is based on 56 interviews with various civil society organisations, trade unions and unemployed groups that engage in the unemployment field in Lyon and Turin. The interview schedule was specifically designed to include not only qualitative in-depth questions, but also sets of standardised questions inquiring into political activities, inter-organisational networks spanning the public and the policy domain, as well as information about actors' organisational structure and resources. Selection of actors started with the systematic examination of official lists of organisations active in Lyon and Turin. Since this effort could only target certain types of actors, the selection was completed through examination of practitioners' publications, access to online sources (blogs of precarious groups, alternative information portals, etc.) and, in particular, through indications coming from actors themselves. At the same time, a wide range of secondary sources, such as organisations' publications, press articles, and official documents from political and institutional authorities, was used to deepen the analysis of further contextual dimensions.

\subsection{The organisational ecology}

A first look at types of actors that are present in the unemployment field shows that Lyon and Turin have very distinct local publics. According to the sample criteria, the study included civil society organisations (CSOs), social movement organisations

\footnotetext{
${ }^{5}$ For example vocational training is coordinated by the Piedmont Region, and the centri per l'impiego
} are managed by the Province. 
(SMOs), religious organisations (ROs), trade unions (TUs) and political parties (PPs, beyond the scope of this article). ${ }^{6}$ Actors were defined by their legal status (CSOs, PPs and TUs), by their close connection with a religious institution (ROs, either formally dependent or not), and by the absence of a clear legal status coupled with an engagement in contentious politics (SMO). ${ }^{7}$ Other actors such as cooperatives and foundations were also included. Without presenting the organisational ecology in detail (see Bassoli and Cinalli 2014), it is important to stress that the two cities differ with respect to the organisations interviewed and the results of the mapping process. The organisational fields are different not only in terms of numbers (19 in Lyon and 26 in Turin) but also in terms of degree of heterogeneity. While Turin stands out as having a highly heterogeneous field, which is made of antagonistic actors (such as social movements and spontaneous committees), pivotal actors for social stability (such as trade unions), and strategic partners to deliver public policies (such as cooperatives and training schools), Lyon is characterised by a much higher homogeneity and a remarkably large number of formal associations, with no presence of spontaneous groups of any kind.

\section{(Table 4.1 about here)}

\subsection{The political involvement of local publics}

Our findings also show major differences in terms of political involvement of local publics in the two cities. The 'two-mode approach' to relational data (David et al. 1941; Everett 2005) can be deployed to evaluate whether civil society actors have been called to participate in decision-making processes as well as the extent to which they have in fact participated. ${ }^{8}$ As already stated, data are directed: for example, they assess whether actors have participated in public decision making, with ties being coded between two sets of nodes - actors and specific administrative levels- and moving from the first to the second. The first finding is that all actors who were called to participate in the local policy process eventually did participate. In particular, four possible roles as participants can be identified: "permanent member of the district or neighbourhood council", "permanent member of a municipal council on specific issues (social services, women, education, etc.)", "occasional member in a municipal committee to solve a specific problem" and "member of a municipal consultation committee or group for a specific policy or issue". 9 Actors could also be invited to participate at other levels. This question, however, was open-ended, and it was later

${ }^{6}$ The political parties are not considered here because they could not be formally invited to policymaking, while, at the same time, they had a privileged and informal access to the political arena. Further information on the sampling strategies and local networks can be found in Bassoli and Cinalli (2014)

7 Therefore we move far from the SNA approach to social movements (Diani and Bison 2004), considering SMO only those informal groups that are part of a social movement, although at some point actors could be in a "social movement process" (ibid. 283). While performing the fieldwork there was not a clear social movement related to either unemployment or precariousness.

8 "In the last 2 years, has your organisation been called to participate in decision-making processes in any of the following ways? [Interviewer: Only when interviewee mentions one, ask] Did your organisation finally participate?"

${ }^{9}$ Since there are four possible roles in the policy-making process, two matrices were created: a 19 by 4 (Lyon) and a 26 by 4 (Turin).
Deleted: Baglioni and Giugni

Deleted: 36

Deleted: 50

Deleted: (Figure 4.1 about here)

Deleted: informal access 
recoded according to five different levels: other local, provincial, regional, national and European. ${ }^{10}$

A synthetic representation of the four main political networks can be offered through measures of 'density' (Wasserman and Faust 1994: 181), which gives the percentage of existing ties out of possible ties. Accordingly, data clearly suggest key differences between Lyon and Turin. As regards political participation at any level, actors in the public domain participate more in Turin $(0.22)$ than in Lyon (0.18). The same holds true for the local level. Yet, while in Turin at the figure is higher for the local level $(0.25)$, for Lyon it is lower (0.13). Thus, the gap between the two cities at the local level is almost three times higher than the gap measured by the general involvement. Overall, the case of Lyon shows that a low degree of political participation, especially at the local level, may well follow a more developed process of (formalised) governance. This result is somewhat counter-intuitive since an inclusive political process is expected to encourage political participation overall, in spite of the decreasing recourse to more radical forms of political mobilisation. By contrast, data for Turin, which is characterised by a more restrictive participatory context, show that local publics participate extensively (the density is much higher than Lyon), especially at the local level.

Figure 4.1 represents the network of participation in formal decision making at any administrative level. The presence of a tie between two nodes (actor ' $A$ ' and level ' $\mathrm{X}$ ') means that that actor (A) participates at the decision-making process at that level (X). Acronyms indicate the legal form: 'A' stands for associations, ' $\mathrm{S}$ ' for informal groups/social movements, ' $\mathrm{T}$ ' for trade unions and ' $\mathrm{C}$ ' for cooperatives. The size of each node increases with the the length of time since the actor first entered the unemployment field, The shape of nodes provides another key piece of information (Lelieveldt et al. 2007): squares are given to actors involved in service provision and circles to other actors (mixed or policy-oriented). ${ }^{11}$ The number of ties in Lyon is lower than in Turin ${ }^{12}$; yet, in both cities half of the actors are not active, while the other half are active at more than one level. Another important distinction can be seen is the different levels involved: while in Lyon all levels are accessed with the exception of the EU level, in Turin the national level is also precluded.

\section{(Fig. 4.1 about here)}

In addition, Figure 4,1 shows that the local level remains the preferred locus for political participation of local publics in the two cities and so the second step of analysis thus concerns the formal decision-making mechanism set up at the local level (Figure 4,2). In order to put forward some of the resource variables used in the research, in Figure 4.2 nodes have a different shape according to economic

${ }^{10}$ In this case, we created two other matrices of 19 by 5 (Lyon) and 26 by 5 (Turin).

${ }^{11}$ The distinction between policy oriented organisations and service oriented organisations is crucial in the third sector. The former target the political system - they try to influence it, or they directly take part in the policy process - whereas the latter rather focus on their clients. These categories are not easily respected empirically, as organizations can do both type of actions simultaneously although usually one of these activities prevails over the other.

12 The measure of centrality is given by the total amount of ties considering the number of nodes, therefore the higher level of centrality in Turin is mirrored by an increased amount of ties (per node) in the figure.

Deleted: 2

Formatted: English (US)
$\begin{aligned} & \text { Deleted: time that an actor dedicates to the unemployment } \\ & \text { issue }\end{aligned}$
issue

Deleted: 2

Deleted: 2

Deleted: so the

Deleted: 3

Deleted: 3 
resources ${ }^{13}$ while size changes proportionally to level of organisational complexity of the collective actor, referred to here as internal articulation ${ }^{14}$. In line with the density figures, the level of participation sharply decreases moving to the local level in Lyon, while it increases in Turin. Clearly both local networks are characterised by a high percentage of isolates ( $63 \%$ and $58 \%)$. Once again, only a rather small number of actors in both cities participate; yet active nodes in Turin have forged more extensive ties than in Lyon.

(Fig. 4.2 about here)

\section{Explaining the political participation of local publics}

So how can we account for these differences between Lyon and Turin? Does the fact that the unemployment field of Turin is formed by spontaneous groups and weak associations account for the differences in participation? Or should we explain this outcome with reference to the development of participatory structure? In what follows, a number of single variables are taken into account, checking them independently. In this way the analysis does not explain the participation of single actors using individual variables as predictive factors; rather, it appraises the extent to which similar actors (grouped according to a given variable) behave similarly. This can be easily done by the ANOVA routine in UCINET (Borgatti et al. 2002). The routine undertakes an analysis of variance using a permutation to assess if the independent variable is evenly distributed among the nodes or if it is (significantly) correlated with the dependent variable. ${ }^{15}$ That is, the significant variables do not explain participation according to a 'causal' direction, yet they do show whether the selected variables are unevenly distributed amongst the actors: ${ }^{16}$ those who participate have either more of a given variable, or less. While one cannot determine the causal direction, it is quite logical to assume the impact of resources on the level of participation rather than vice-versa.

The test has been run on a number of variables, many of which are not evenly distributed. These variables include different kinds of resources (budget, recruited staff, office ownership), different dimensions of formalisation (level of internal articulation, being registered), different aims (policy-oriented service-oriented actors, actors running public programmes),${ }^{17}$ as well as different levels of activity (only local, local and national, only national) and of information inflow (as a proxy of visibility by the public authorities). ${ }^{18}$ The significant variables, listed in Table 5.1, reinforce the

\footnotetext{
${ }^{13}$ Organisations with a budget lower than 10 thousand euro are represented by a circle (as well as missing), between 10 and 200 thousand are square, triangle above 200 thousand.

14 The minimum articulation is given by organisations with only an assembly (score 1), while the higher level is given by those organisations with a board, a leader / president, a chairperson, a secretary, a spokesperson, a treasurer, a general assembly, and committees (score 8).

${ }^{15}$ In the permutation test the standard assumptions on independence and random sampling are not required.

${ }^{16}$ The routine measures the correlation between the dependent variable (degree centrality - that is, the number of ties each actor has) and the independent variable considered.

${ }_{17}$ The first two categories have been considered both mutually exclusive and not, the third is an independent category.

18 This variable has been measured using network data, considering information received by the local organisation by given political actors (or levels).
} 
general idea about the open governance structure of Lyon vis-à-vis Turin. Indeed the role of resources is more important in Turin than in Lyon. Out of all possible variables, quite a few resources are more abundant across the actors that participate in the Italian city: the degree of institutionalisation, the possibility of having full-time workers, the capacity for running public-programmes. Only one variable is crucial in both contexts, namely the provision of services (with service providers participating to a greater extent in both cities). Focussing on local participation, the overall picture does not change. While resources affect the French case (Table 5.1) only via the employment of part-time workers, the Italian case still shows the higher salience of resources: length of activity (the older the actor the more it participates), internal articulation (the more articulated the actor, the more it participates), finances (the richer the actor the more it participates), and the diversification of service provision (the actors which diversify the most are also those which participate the most).

\section{(Tab. 5.1 about here)}

Generally speaking, participation in Lyon seems randomly distributed. As regards participation at all levels, only one variable is not evenly shared among the actors (the diffusion of advocacy services), while for local participation a single variable seems relevant (the distribution of part-time workers). Hence, data suggest that the political context in Lyon may well overcome individual limitations of resources. By contrast, scarce political opportunities and thinner processes of governance in the case of Turin allow for participation of only some specific actors, namely, the older, more formally structured, richer organisations with the capacity for running public-programmes, as well as those that devote themselves the most to service-provision for internal members.

Further differences emerge when we consider the openness of the political system more specifically. A crude indicator of openness is represented by the different magnitude of flow of information received by organisations. Data were gathered on whether the organisation had been receiving information from any specific level of government (European, national, regional, local or district) ${ }^{19}$. In this case, the density of the French information network is much higher compared to the Italian network, that is, 0.495 against 0.231 . This means that, out of all possible connections, $49.5 \%$ of them have been forged in the unemployment field in Lyon, but only $23.1 \%$ have been forged in Turin. Since some levels of government beyond the local may be crucial in one city but irrelevant in the other (for example, the national level that is so quintessential under the long-standing tradition of French Republicanism), the local flow of information has also been singled out. In this case, figures are much more similar for the two cities, with 0.342 for Lyon and 0.365 for Turin. Nonetheless this similarity is only apparent, since the network patterns are quite different, as can be grasped from Figure 5.1. The networks have been graphed so as to group the actors according to the number of ties that they have forged, and according to the direction of these ties.

\section{(Fig. 5.1 about here)}

\footnotetext{
19 "Regardless of whether you ever get invitations to participate in decision-making processes, does your organisation receive official information concerning the decision-making processes on questions relevant for your organisation from any of these authorities?" This question produced (again) two
} matrices of 19 by 5 (for Lyon) and 26 by 5 (for Turin). 
As expected, the national level plays a major role in Lyon (with the district being almost absent), while the Turin network contains more isolates than that for Lyon. Yet some specifications are necessary given the different organisational ecology of the two cities. Considering the legal form of organisations in Turin, a strong correlation can be found with network centrality. Thus the fact of being a social movement organisation deeply hinders the possibility of having equal access to the policy domain in terms of 'receiving information' (Table 5.2). Measures have been assessed through two main variables. The first one is the 'legal form', distinguishing between trades unions, formal organisations and 'other' (that is social movements and cooperatives). The second variable focuses on 'degree of institutionalisation', ranking organisations alongside the distinctions between SMOs (1), associations (2), cooperatives (3), and trades unions (4). While the first variable works well when accounting for flows of information at the local level (R square 0.43 at the level of $99 \%)$, the second variable performs equally well in terms of the overall picture ( $R$ square 0.42 at the level of 99\%). Crucially, the SMOs are isolated, alongside with some trade unions, while cooperatives, associations and the largest trades unions take better advantage of the communication channels in Turin.

\section{(Table 5.2 about here)}

As regards the social capital created by the overall relational structure in which local publics are embedded, the ANOVA procedure can be useful to correlate the degree centrality in different networks. This undertakes the variance analysis comparing the distribution of the centrality in two different networks. The procedure has been used to assess the correlation between centrality in the participation network and three other variables: societal importance (level of centrality in the local field of unemployment, as perceived by the organisation ${ }^{20}$ or by others ${ }^{21}$ ), centrality in information networks, and the political involvement in networks created by wider civil society partnerships beyond the unemployment field.

Findings show that in both cities participation at the local level co-varies with participation at the national level, yet with some crucial differences. In Lyon the impact is much stronger and works only in one direction: the local participation 'moves' the participation at all levels (R-square 0.577). By contrast, in Turin the two types of participation move together but to a lesser extent (R-square equal 0,268 and 0.299 respectively). At the same time, information stands out as a key factor in Turin. This finding fits with the idea that the political context is negative for civil society actors of the Italian city. Its local public is cut off, while the rare channels are selective and biased towards 'well-known' actors so that information is provided only to the 'usual suspects'. Clearly, information strongly co-varies with both participation and local participation (at a 99\% level of confidence). By contrast, the 'social centrality is irrelevant, since scores in both cities cannot explain political participation. This is again a counter-intuitive finding, which hardly matches the

${ }^{20}$ The measure was the out-degree centrality, that is, the number of perceived partners which a given organisation has.

${ }_{21}$ The measure was the in-degree centrality, that is, a measure of popularity, since it refers to the number of times that a given organisation has been mentioned as a partner by other actors. 
quintessential expectations of the social capital literature.

(Table 5.3 about here)

\section{Conclusions}

In this article we have conducted a comparison of the multi-level and multiorganisational field of unemployment in Lyon and Turin in order to analyse, first, variations of participation of local publics, and second, the main explanatory factors accounting for cross-city variations. The focus on unemployment has allowed for analysis of a field that has become increasingly contentious throughout the 2000 s, and which may thus be exemplary for understanding the variable impact of different policy answers to potentially contentious issues of the future. In particular, our research has shed light on the complex dynamics that operate across the public domain (where local publics mobilise) and the policy domain (where elites and institutions shape their interventions), with the aim of contributing to the development of a set of theoretical approaches that deal with political participation within the two distinct scholarly traditions of governance and political opportunities.

Our main point is that even the most articulated sets of inclusive arrangements fostering the participation of local publics need to be appraised in terms of actual outcomes across the public and policy domains. Following the nexus between context and behaviour that is at the core of the scholarship of opportunities, more theorisation is needed in the governance field about the consequences of variable policy processes for political participation. We have thus argued that a number of crucial questions need to be asked about the complex interactive dynamics that enable stakeholders to engage across the public and the policy domains. Accordingly, amongst the main findings, we have shown that a low level of participation may well fit with more extensive channels of governance (just as it happens in Lyon), whilst higher levels of participation may well follow situations of underdeveloped governance (as in the case of Turin). That is, the allegedly virtuous relationship between governance and participation is in our research far from being proved, warning us that a more thorough examination of the normative underpinnings of the same concept of governance is necessary.

Furthermore, our analysis has revealed that provision of services, overall resources, and time devoted to the specific issue of unemployment (amongst the other possible issues competing for members' attention) stand out as predictors of higher levels of participation in Turin, whereas groups with fewer resources find a better place within the more inclusive structure of Lyon's governance regime. We have thus shown that more attention has to be focused on specific interactions taking place between the exogenous characteristics of political contexts within which local publics are situated on the one hand, and other endogenous explanations in terms of resources and main orientations on the other. Findings indicate that orientations may indeed play a crucial role, especially in more amorphous and locally-rooted contexts such as Turin. In the Italian city, more established groups define the field. Yet, this happens not just because these groups have an official status, as in Lyon (although legal status grants access to information that may increase the chance of being politically involved), but also because they provide specific services. As regards resources, our analyses have dealt with financial capabilities, internal articulation, as well as diversification in the 
scope of service provision. We have thus found that the impact of the political context needs to be appraised in terms of its interaction with the availability of certain resources, for example when governance is variably (un)structured. Most crucially, our findings are in line with earliest arguments in the literature stressing the 'tyranny of structurelessness' (Freeman 1973), or less normatively, the fact that resources have a greater impact upon participation in the absence of formal structures. This is a further reason to continue to inquire into the vices and virtues of governance. 


\section{References}

Baglioni, S., Della Porta D. \& Graziano, P. (2008) The contentious politics of unemployment: the Italian case in comparative perspective, European Journal of Political Research, 47 (6), pp. 827-851.

Bassoli, M. (2010) Local Governance Arrangements and Democratic Outcomes, Governance, An International Journal of Policy, Administration, and Institutions, 23(3), pp. 485-508.

Bassoli, M., (2012) Participatory Budgeting in Italy: An Analysis of (Almost Democratic) Participatory Governance Arrangements. International Journal of Urban and Regional Research, 36(6), pp.1183-1203.

Bassoli, M \& Cinalli, M. (2014) Networks within the Multi-Organizational Field of Unemployment: A Tale of Seven Cities in Europe. In S. Baglioni \& M. Giugni (eds.) Civil Society Organizations, Unemployment, and Precarity in Europe. Houndmills,

Basingstoke, Hampshire, England; New York: Palgrave Macmillan, pp. 109-135.

Bassoli, M. \& Polizzi, E. (2011) (eds.) La governance dei territori. Partecipazione e rappresentanza della società civile nelle politiche locali, Milano: Angeli.

Borgatti, S.P. (2002) NetDraw: Graph Visualization Software. Harvard: Analytic Technologies

Borgatti, S.P., Everett, M.G. \& Freeman, L.C. (2002) Ucinet for Windows: Software for Social Network Analysis. Harvard, MA: Analytic Technologies.

Broadbent, J. (1998), Environmental Politics in Japan Networks of Power and Protest, Cambride, Cambridge University Press.

Cinalli, M. (2010) "National Multi-Organisational Fields and Unemployment in Europe: A Comparison of Britain and France", in Royall F. and D. Chabanet (eds.), Mobilising Against Marginalisation in Europe, Cambridge Scholars Publishing: Cambridge.

- $\quad$ (2007a) "Between horizontal bridging and vertical governance: Pro-beneficiary movements in New Labour Britain”, in Pordue D. (ed.), Civil societies and social movements: potentials and problems, London: Routledge, pp. 88-108.

- (2007b), The Impact of Relational Structures upon Collective Action: A Comparison of Unemployment and Asylum in New Labour Britain, CEVIPOF Working Paper, 23.

Cinalli, M. \& El Hariri, A. (2011), "Contentious Opportunities in the Field of Immigration in France and Italy", in Carmel E., Cerami A. and T. Papadopoulos (eds.), Migration and Welfare in the 'New' Europe. Social Protection and the Challenges of Integration, Policy Press: Bristol.

Cinalli, M. \& Giugni, M. (2010), "Mapping the Contentious Politics of Unemployment in Europe", in Giugni M. (ed), The Contentious Politics of Unemployment in Europe: Welfare States and Political Opportunities, Palgrave: London.

Cinalli, M. \& Füglister, K. (2008), Networks and Political Contention over Unemployment: A Comparison of Britain, Germany and Switzerland, Mobilization : An International Journal, 13(3), pp. 259-76.

Christopoulos, D. (2008) The Governance of Networks: Heuristic or Formal Analysis?, Political Studies, 54/2.

Christopoulos, D. \& Quaglia, L. (2009) Influence and Brokerage: Network Constraints in EU Banking Regulation, Journal of Public Policy, 29/2, pp. 179200.

Curtis, R.L. \& Zurcher L.A. (1973) Stable resources of protest movements: The 
multi-organizational field, Social Forces 52, pp. 53-61.

Della Porta, D. \& Andretta, M. (2002) Changing forms of environmentalism in Italy: the protest campaign on the high speed railway system, Mobilization : An International Journal, 7(1), pp. 59-77.

Diani, M. (1992) "Analysing social movement networks" in Diani M. and R. Eyerman (eds.), Studying Collective Action. London: Sage.

- (1995) Green Networks: A Structural Analysis of the Italian Environmental Movement. Edinburgh: Edinburgh University Press.

Diani, M. \& Bison I. (2004) Organizations, coalitions, and movements, Theory and Society, 33, pp. 281-309.

Diani, M. \& McAdam, D. (2003) Social Movements and Networks. Relational Approaches to Collective Actions. Oxford: Oxford University Press.

Dowding, K. (1995) Model or Metaphor? A Critical Review of the Policy Network Approach, Political Studies, 45 (1), pp. 136-58.

- $\quad$ (2001) There Must be End to Confusion: Policy Networks, Intellectual Fatigue, and the Need for Political Science Methods Courses in British Universities, Political Studies, 49 (1), pp. 89-105.

Eisinger, P. K. (1973) The Conditions of Protest Behaviour in American Cities, American Political Science Review, 67, pp.11-28.

Esping- Andersen, G. (1990) The three worlds of welfare capitalism, Princeton: Princeton University Press.

Fabbrini, S. (2001) Features and Implications of Semi-Parliamentarism: The Direct Election of Italian Mayors, South European Society and Politics, 6(2), pp. 47 70.

Feiock, R. \& Scholz, J. (2010) (eds.) Self-Organizing Governance: Collaborative Mechanisms to Mitigate Institutional Collective Action Dilemmas. New York: Cambridge University Press.

Ferrera, M. (1996) The 'Southern Model' of Welfare in Social Europe, Journal of European Social Policy, 6(1), pp. 17-37.

Freeman, J. (1973) "The Tyranny of Structurelessness." Berkeley Journal of Sociology, 17, pp.151-64.

Gamson, W.A. \& Meyer, D. (1996) "The Framing of Political Opportunity", in McAdam D., McCarthy J.D. and M.N. Zald (eds.), Opportunities, Mobilizing Structures, and Framing: Comparative Applications of Contemporary Movement Theory, CUP: Cambridge, pp. 275-90.

Glendinning, C., Powell, M. \& Rummery, K. (eds.) (2002) Partnerships, New Labour and the governance of welfare, Bristol: The Policy Press.

Giugni, M., Berclaz, M. \& and Füglister, K. (2009) "Welfare States, Labour Markets, and the Political Opportunities for Collective Action in the Field of Unemployment: A Theoretical Framework." in Giugni M. (ed.), The Politics of Unemployment in Europe: State and Civil Society Responses, Aldershot: Ashgate, pp. 133-149.

Giugni, M. \& Passy, F. (2001) (eds.) Political Altruism? Solidarity Movements in International Perspective. Lanham, Md.: Rowman \& Littlefield Publishers.

Gould, R.V. (1995) Insurgent Identities: Class, Community and Protest in Paris from 1848 to the Commune. Chicago: University of Chicago Press.

Grote, J. (2008) "Local Governance and Organized Civil Society: Concepts and Applications." Paper presented at the CINEFOGO conference "New Forms of Local Governance and Civil Society," Trento, June 20-21.

Grote, J.\& Gbikpi, B. (2002) Participatory Governance, Opladen: Leske \& Budrich. 
Harlow, C. \& Rawling, R. (2006) Promoting Accountability in Multi-Level Governance: A Network Approach. European Governance Papers (EuroGov), C-06-02, http://www.connex-network.organizzazioni/eurogov/pdf/egp-connexC-06-02.pdf.

INSEE (2011) Lyon - Evolution et structure de la population, http://www.statistiqueslocales.insee.fr/FICHES/DL/DEP/69/COM/DL_COM69123.pdf

ISTAT (2011) tasso di disoccupazione - livello provinciale, http://dati.istat.it/ index.aspx?queryid $=298$

Jessoula M., Graziano, P. \& Madama, I. (2010) 'Selective Flexicurity' in Segmented Labour Markets: The Case of Italian 'Mid-Siders, Journal of Social Policy, 39(4), pp. 561-583.

John, P. (2001) Local Governance in Western Europe, London : Sage.

Jordan, A. (2001) The European Union: an evolving system of multi-level governance ... or government?, Policy \& Politics, 29.2, pp.193-208.

Kingdon, J. (1995), Agendas, alternatives, and public policies (2d ed.), Boston: Little, Brown.

Kitschelt, H. (1986) Political Opportunity Structures and Political Protest: AntiNuclear Movements in Four Democracies, British Journal of Political Science 16 , pp. 57-85.

Kriesi, H., Koopmans, R., Duyvendak, J.W. \& Giugni, M. (1995) New Social Movements in Western Europe. A Comparative Analysis. Minneapolis, MN: University of Minnesota Press.

Knoke, D. \& Kuklinsky, J. (1982) Network Analysis. London: Sage.

Lelieveldt, H., Astudillo, J. \& Stevenson, L. (2007) "The Spectrum of associational activities: from self-help to lobbying", in W. Maloney and S. Rossteutcher (eds.), Social Capital and Associations in European Democracies, London: Routledge, pp. 81-95.

Lin, N. (2001) Social Capital: A Theory of Social Structure and Action. New York: Cambridge University Press.

Mayntz, R. (2003) "From Government to Governance: Political Steering in Modern Societies" Paper for the Summer Academy on IPP, Wuerzburg, September, 711 .

Marsh, D. \& Smith, M. J. (2001) There is more than one way to do political science: on different ways to study policy networks, Political Studies, 49, pp. $528-41$.

Marshall, D.J. \& Staeheli, L. (2015). Mapping civil society with social network analysis: Methodological possibilities and limitations. Geoforum, 61, pp.56-66.

McCarthy, J.D. \& Zald, M.N. (1977) Resource Mobilization and Social Movements: A Partial Theory, American Journal of Sociology 82, pp. 1212-41.

Obershall, A. (1973) Social Conflict and Social Movements. Englewood Cliffs: Prentice-Hall.

OECD (2010) Online OECD Employment database, webpage www.oecd.org/document/34/0,3343,en_2649_33927_40917154_1_1_1_1,00.ht $\mathrm{ml}$ (last access 10/10/10).

Osborne, S. (2007) Theory and Practice in International Perspective, London: Routledge.

Piselli, F. \& Ramella, F. (2008) Patti sociali per lo sviluppo locale, Roma: Donzelli.

Polizzi, E. (2011) “Conclusioni” in Bassoli M. and E. Polizzi (eds.), La governance dei territori. Partecipazione e rappresentanza della società civile nelle politiche locali, Milano: Angeli. 
Raab, C. (2001) Understanding policy networks: a comment on Marsh and Smith, Political Studies, 49, pp.551-6.

Ranci, C. (1999) Oltre il welfare state, Bologna, Il Mulino.

Ranci, C. \& Montagnini, E. (2009), "The impact of commodification of social care on the role and identity of third sector in Italy" in Zimmer A. and A. Evers (eds.) Third Sector Organizations Facing Turbulent Environments: Sports, Culture and Social Services in five European countries, Frankfurt: Nomos.

Rhodes, R.A.W. (1996) The new governance: governing without government. Political Studies, 54, pp. 652-667.

- (1997) Understanding Governance: Policy Networks, Governance, Reflexivity and Accountability, Buckingham: Open University Press.

Scott, J. (2000) Social Network Analysis. London: Sage.

Sohn, C. \& Giffinger, R. (2015) A Policy Network Approach to Cross-Border Metropolitan Governance: The Cases of Vienna and Bratislava. European Planning Studies, 23(6), pp.1187-1208.

Sullivan, H. \& Skelcher, C. (2002) Working Across Boundaries: Collaboration in Public Services, Basingstoke: Macmillan-Palgrave.

Tarrow, S. (1998) Power in Movement. Cambridge: Cambridge University Press.

Tilly, C. (1978) From Mobilization to Revolution. Reading, Mass.: Addison-Wesley.

Torpe, L., \& Ferrer-Fons, M. (2007) "The internal structure of associations", in W. Maloney and S. Rossteutcher (eds.), Social Capital and Associations in European Democracies, London: Routledge, pp. 81-95

Wasserman, S. \& Faust, K. (1994) Social Network Analysis: Method and Applications. Cambridge: Cambridge University Press.

Correspondence Address:

Matteo Bassoli, eCampus Online University - School of Law, Via Isimbardi 10 , Novedrate (CO) 22060, Italy. 